\title{
MANAJEMEN STRATEGI KEPALA SEKOLAH DALAM MENINGKATKAN MUTU PADA PENDIDIKAN ANAK USIA DINI DI CAKRANEGARA MATARAM
}

\author{
Ida Ayu Made Sukadewi \\ STAHN Gde Pudja Mataram
}

\begin{abstract}
ABSTRAK
Pendidikan anak usia dini merupakan pendidikan yang ditujukkan bagi anak sejak lahir hingga usia 6 tahun, karena usia tersebut anak mengalami perkembangan intelegensi yang paling optimal. Menejemen strategi kepala sekolah dalam meningkatkan mutu sekolah dilakukan dengan baik sehingga minat orang tua dalam menyekolahkan anaknya sangat tinggi dengan peningkatan jumlah peserta didik. Prestasi peserta didik juga semakin meningkat saban tahun dari berbagai kompetisi yang di ikuti oleh peserta didik dan pendidik.

Penelitian ini menggunakan metode kualitatif dengan analisis secara deskriftif kualitatif. Pengumpulan data dilakukan dengan teknik observasi, wawancara, dokumentasi dan dilakukan pengecekan keabsahan data melalui kredibilitas, dependabilitas dan konfirmabilitas. Dalam penelitian ini menggunakan teori mutu dari Philip Crosby dan teori fungsional struktural.

Hasil penelitian ini menunjukkan manajemen strategi kepala sekolah untuk meningkatkan mutu pada lembaga sekolah melalui perencanaan, pengorganisasian, penggerakan dan pengawasan yang dilakukan dengan pendekatan kekeluargaan dan komitmen yang kuat dalam bekerja sama mengimplementasikan kegiatan sekolah melalui tim yang baik. Strategi yang digunakan oleh kepala sekolah yaitu melalui pemberian arahan kepada guru dalam proses belajar mengajar, pembinaan khusus untuk pendidik yang mengalami kesulitan dalam menjalankan tugas sekolah, meningkatkan profesional guru melalui pelatihan dan seminar pendidik, melakukan penataan terhadap sarana dan prasarana sekolah, memberikan pelayanan pendidikan bagi peserta didik untuk memiliki prestasi baik secara akademik maupun non akademik. Keseluruhan dari strategi yang digunakan oleh kepala sekolah mengacu pada prinsip kaizen yaitu perbaikan mutu pendidkan di sekolah dengan sedikit demi sedikit tetapi berkelanjutan.
\end{abstract}

Kata Kunci: Manajemen strategi, kepala sekolah dan mutu pada PAUD Pelangi

\section{PENDAHULUAN}

Pendidikan adalah suatu kegiatan dalam proses pengembangan segala potensi yang dimiliki, baik dari segi intelektual dan psikologis. Oleh karena itu pendidikan pada hakikatnya bersifat semesta, meliputi seluruh aspek kehidupan mencakup seluruh unsur kebudayaan seperti; moral, etika, estetika, logika dan keterampilan yang serasi dan terpadu dengan pembangunan nasional dan budaya di lingkungan masyarakat. Sebagaimana 
dipahami secara khusus bahwa pendidikan adalah usaha sadar dan terencana untuk menyiapkan peserta didik melalui kegiatan bimbingan, pengajaran, dan latihan bagi peranannya dimasa yang akan datang (Sagala, 2010: 15). Pendidikan memegang peranan yang sangat penting bagi kehidupan manusia di dunia ini, melalui pendidikan manusia dapat mengangkat derajat hidup dan membangun kehidupan yang lebih baik.

Sekolah sebagai lembaga formal yang menyelenggarakan kegiatan belajar mengajar yang didukung oleh beberapa unsur untuk mencapai keberhasilan pada tujuan yang telah ditetapkan. Keberhasilan dan mutu sekolah dalam menyelenggarakan misinya ditentukan oleh hasil kerja atau output dari sekolah tersebut, seperti tenaga pendidik, sarana dan prasarana, biaya, jumlah peserta didik, masyarakat serta pendukung lainnya yang dikelola dengan baik. Pendidikan Anak Usia dini yang selanjutnya dalam penelitian ini diakronimkan menjadi (PAUD) merupakan pendidikan yang ditunjukkan bagi anak sejak lahir hingga usia 6 tahun yang diselenggarakan melalui jalur pendidikan formal, nonformal dan atau informal.

PAUD sebagai bagian integral dalam sistem pendidikan Nasional yang mendapatkan perhatian yang sangat besar dari pemerintah. Kecerdasan anak baik dari motorik kasar, motorik halus, spiritual, dan keterampilan seni, berkembang dengan baik apabila semua komponen dalam dunia pendidikan khususnya PAUD dapat saling bahu membahu mewujudkan generasi penerus bangsa yang berkualitas serta mampu bersaing dengan negara maju lainnya. Semua komponen yang terdapat dalam suatu organisasi pendidikan, dapat terimplementasikan sesuai dengan tujuan yang akan dicapai melalui proses manajemen.

Manajemen merupakan suatu kegiatan pencapaian tujuan yang melibatkan sumber daya manusia dan material secara efektif dan efisien. Inti dari manajemen adalah leadership, yaitu kemampuan untuk menggerakan orang-orang mengikuti pemimpin (Sagala, 2010: 50). PAUD akan menjadi bermutu apabila kepala sekolah sebagai pemimpin pendidikan mimiliki kecakapan dalam mengelola dan mengatur segala sumber daya manusia dan material serta mampu mengadakan kerja sama dengan lembaga sekolah lain dan masyarakat sekitar, sehingga dapat menghasilkan output dan outcame yang bermutu.

Setiap lembaga PAUD memiliki keunggulan yang berbeda dengan lembaga lainnya, khususnya yang ditunjukkan oleh PAUD Pelangi yang merupakan salah satu sekolah formal yang berada di daerah Cakranegara Mataram. PAUD Pelangi menerapkan sebuah sistem 
lembaga dengan ciri khas yang jarang bisa ditemukan pada lembaga PAUD lain yang ada di Kota Mataram, di antaranya yaitu pencapaian setiap program lembaga selalu dilakukan dengan melalui koordinasi yang demokratis antara ketua yayasan, kepala sekolah dan guru yang dilakukan melalui sistem kekeluargaan. Adanya keunggulan yang terpancar dalam proses mendidik peserta didik yakni terbangunnya harmonisasi antara guru dengan atasan, antara guru dan orang tua peserta didik yang kemudian tercover dalam kurikulum 2013. Selain itu minat orang tua dalam menyekolahkan anaknya sangat tinggi, hal ini terlihat dari jumlah peserta didik setiap tahun ajaran baru selalu mengalami peningkatan meskipun tidak terpengaruh oleh SPP yang selalu bertambah. Munculnya ketertarikan lembaga PAUD lain, seperti keinginan untuk mengirim salah satu gurunya ke PAUD Pelangi untuk mempelajari beberapa strategi yang diterapkan dalam mengelola peserta didik, sarana dan prasarana pendidikan. Selain itu eksistensi yang ditunjukkan oleh lembaga PAUD Pelangi terlihat dari beberapa bukti nyata melalui beberapa prestasi yang telah diperoleh dari beberapa hasil juara dari kompetisi yang pernah di ikuti oleh peserta didik dan pendidik. Dengan demikian, PAUD Pelangi dipandang representatif untuk dijadikan lokasi penelitian yang sesuai dengan fokus penelitian.

Tentunya hal ini merupakan sesuatu yang menarik untuk ditelusuri lebih mendalam agar dapat dipahami bagaimana manajemen strategi kepala sekolah tersebut dalam meningkatkan mutu lembaga sekolah pada jenjang pendidikan anak usia dini.

\section{METODE PENELITIAN}

Rancangan yang digunakan dalam penelitian ini yaitu metode kualitatif yang dimaksudkan untuk memproduksi ilmu-ilmu lunak yang esensinya sebagai sebuah metode pemahaman atas suatu keunikan dan dinamika lingkungan sehingga penelitian kualitatif bersifat luas dan kompleks (Umar, 2010:4-5). pendekatan yang digunakan yaitu pendekatan deskriptif kualitatif yang bersifat interpretatif dengan tujuan dapat mendeskripsikan dan menganalisis setiap fenomena atau peristiwa yang memiliki potensi dalam memberikan pemahaman terhadap manajemen strategi kepala sekolah dalam meningkatkan mutu pada lembaga PAUD Pelangi di Cakranegara Mataram. 
Dalam penelitian ini jenis datanya adalah kuantitatif berupa tabel dan grafik berupa angka-angka dan kualitatif yaitu tindakan-tindakan oleh subyek penelitian sesuai dengan pertanyaan yang dikemukakan peneliti dan pengamatan yang dilakukan oleh peneliti dengan merujuk kepada fokus penelitian (Meleong dalam Zaenab, 2015:52). Teknik pengumpulan data yang digunakan dalam penelitian ini adalah (1) Observasi, (2) Wawancara, (3) Dokumentasi. Teknik analisis data menggunakan tiga langkah, yaitu pertama menggunakan langkah reduksi (pemilihan data), kedua Penyajian Data (Display data) merupakan tahap kedua setelah data direduksi dengan tepat dan benar. Ketiga penyimpulan data. Untuk memeriksa keabsahan data dalam penelitian ini diperlukan teknik pengecekan keabsahan data yang meliputi yaitu: Pengecekan Kredibility, Pengecekan Depenability, dan Pengecekan Confirmability.

\section{PEMBAHASAN}

Manajemen strategi adalah serangkaian keputusan dan tindakan yang telah dipilih sebagai suatu jalan untuk mencapai tujuan bersama oleh kepala sekolah dalam meningkatkan mutu pada PAUD Pelangi di Cakranegara Mataram berdasarkan pada perencanaan yang dilakukan oleh kepala sekolah dan seluruh tenaga pendidik melalui analisis lingkungan internal dan eksternal serta memilih strategi yang digunakan untuk mengimplementasikan program kegiatan sekolah. Untuk dapat mencapai tujuan yang telah ditetapkan bersama, kepala sekolah melakukan pembentukan tim untuk pembagian tugas setiap guru sesuai dengan bakat, minat, pengalaman dan keterampilannya.

Peningkatan mutu sekolah ditentukan oleh kerja sama tim yang sangat kuat, kepala sekolah selalu melakukan pendekatan secara kekeluargaan kepada seluruh komponen sekolah dengan tujuan kegiatan sekolah dapat tercapai secara efektif dan efisien. Untuk menjamin mutu dari setiap program sekolah, pengawasan yang dilakukan oleh kepala sekolah tidak otoriter namun lebih pada pemberian arahan dan bimbingan. Prinsip pengawasan yang dilakukan dengan mencegah kesalahan yang terjadi dan selalu melakukan perbaikan secara bertahap dari fasilitas, sarana dan prasarana sekolah, pengelolaan keuangan, pengelolaan peserta didik dan tenaga pendidik. 
Hal tersebut sesuai dengan teori fungsional struktural yaitu Manajemen organisasi akan di orientasikan pada bagaimana mengkondisikan orang-orang dalam organisasi untuk dapat dinamis, saling tergantung satu sama lain, memiliki hubungan yang dinamis baik internal maupun eksternal, dan beradaptasi dan membentuk budaya organisasi sekolah (Tim penyusun, 2011:79).

Pada implementasi manajemen kepala sekolah dalam meningkatkan mutu sekolah, dimulai dengan perencanaan yang dilakukan bersama oleh kepala sekolah dan pendidik dengan prinsip bekerja sama dalam satu tim. Untuk mencapai tujuan secara efektif dan efisien dilakukan pembagian tugas yang sesuai dengan kemampuan setiap guru, sehingga tugas dan tanggung jawab yang diberikan oleh kepala sekolah dapat tercapai sesuai dengan perencanaan. Kepala sekolah menggerakan pendidik melalui motivasi, bimbingan dan pengarahan untuk dapat mencegah setiap kesalahan yang akan terjadi. Pengawasan yang dilakukan oleh kepala sekolah untuk menjamin kepuasan dari pelanggan internal dan external lebih mengarah untuk memberikan bimbingan dan memperbaiki dengan cepat setiap kendala yang ada sehingga mutu pada sekolah dapat ditingkatkan.

Dengan demikian berdasarkan pemaparan di atas, bahwa implementasi manajemen strategi kepala sekolah dalam meningkatkan mutu pada PAUD Pelangi dilakukan melalui perencanaan, pengorganisasian, penggerakan dan pengawasan oleh tim yang kuat dengan prinsip perbaikan secara terus menerus tanpa adanya kekurangan. Kepuasan orang tua peserta didik sebagai pelanggan eksternal menampakkan kesetiaan dalam menggunakan pelayanan pendidikan di PAUD Pelangi, hal ini terbukti dari peserta didik yang terdaftar merupakan kerabat atau keluarga dari orang tua peserta didik sebelumnya.

Hambatan Dalam Implementasi Manajemen Strategi Kepala Sekolah dalam Meningkatkan Mutu Pada PAUD Pelangi di Cakranegara, Hambatan yang ditemukan dalam implementasi manajemen strategi kepala sekolah dalam meningkatkan mutu pada PAUD Pelango Cakranegara, diantarnya yaitu; dalam memberikan pelatihan keterampilan kepada anak-anak belum dilakukan oleh tenaga pelatih yang khusus pada bidangnya, setiap anakanak akan dilatih sesuai dengan bakat dan minatnya oleh ibu guru yang telah diberikan tanggung jawab langsung oleh kepala sekolah dalam memberikan pelatihan. 
Berdasarkan dari ketiga penjelasan di atas menunjukkan bahwa kendala yang dihadapi oleh kepala sekolah dalam upaya meningkatkan mutu sekolah adalah kurangnya fasilitas, sarana dan prasarana sekolah, dan tidak adanya wadah penyalur aspirasi wali murid kepada pihak sekolah. Sesuai dengan analisis SWOT yang telah dilakukan yaitu dengan menyediakan para pengambil keputusan organisasi akan informasi yang dapat menyiapkan dasar dan pertimbangan dalam pengambilan keputusan dan tindakan. Analisis SWOT digunakan untuk menemukan aspek-aspek yang menjadi hambatan dalam implementasi manajemen kepala sekolah dalam meningkatkan mutu pada PAUD Pelangi Cakranegara.

Berdasarkan teori mutu Philip Crosby, mengungkapkan bahwa segala sesuatunya dikerjakan dengan metode yang tepat, sejak pertama dan selamanya. Membangun tim peningkatan mutu atas dasar komitmen. Melakukan kegiatan perbaikan, pengawasan harus melakukan kerja sama dengan para staf untuk memperbaiki mutu yang rendah. Perencanaan tanpa cacat (zero defects) harus diperkenalkan dan di pimpin oleh tim peningkatan mutu yang bertanggung jawab terhadap implementasinya ( Sallis, 2015: 97-101).

Solusi yang digunakan untuk mengatasi hambatan pada implementasi manajemen strategi kepala sekolah dalam meningkatkan mutu PAUD Pelangi di Cakranegara, Untuk mengatasi beberapa kendala dalam implementasi manajemen strategi kepala sekolah dalam meningkatkan mutu pada PAUD Pelangi dilakukan melalui beberapa strategi yaitu, kepala sekolah dapat mendatangkan secara khusus pelatih yang membidangi keterampilan pada bidangnya, sehingga mutu pelayanan pendidikan dan pembekalan keterampilan kepada peserta didik di PAUD Pelangi dapat tercapai secara lebih maksimal. Untuk mengatasi hambatan pada fasilitas, sarana dan prasarana sekolah, kepala sekolah sudah melakukan upaya untuk mengoptimalkan fungsi dan penggunaan sarana dan prasarana sekolah sehingga kegiatan yang telah dilaksanakan dapat tercapai dengan baik.

Upaya yang dapat dilakukan oleh kepala sekolah untuk meningkatkan kerja sama antara orang tua peserta didik dan sekolah yaitu melalui pertemuan rapat yang dilakukan selama tiga kali dalam satu tahun dan adannya hari konsultasi tentang perkembangan peserta didik yang dilaksanakan pada setiap hari Kamis-Sabtu. Dengan diadakannya rapat pertemuan diharapkan segala kegiatan sekolah dapat disosialisasikan kepada orang tua peserta didik. Melalui upaya adanya hari konsultasi perkembangan anak yang dilaksanakan setiap hari 
Kamis-Sabtu, bertujuan untuk meningkatkan kerja sama orang tua seperti didik dan pihak sekolah dalam proses mendidik anak dan setiap perkembangan peserta didik dapat diketahui langsung oleh orang tuanya.

Hal tersebut sesuai dengan teori kualitas prinsip Crosby yaitu; Pertama, ide bahwa mutu itu gratis. Menurut Crosby, terlalu banyak pemborosan dalam sistem saat mengupayakan peningkatan mutu. Kedua, ide bahwa kesalahan, kegagalan, pemborosan, dan penundaan waktu serta semua hal yang tidak bermutu lainnya bisa di hilangkan jika institusi memiliki kemampuan untuk itu. Ini adalah gagasan tanpa cacatnya yang kontroversial. Kedua ide tersebut sangat menarik jika diterapkan dalam dunia pendidikan. Gagasan bahwa

peningkatan mutu dapat membantu organisasi menghilangkan kegagalan, khususnya kegagalan pelajaran dan murid merupakan gagasan yang sering kali diabaikan oleh sebagian besar institusi.

Dengan demikian, segala hambatan yang dihadapi oleh kepala sekolah PAUD Pelangi Cakranegara pada implementasi manajemen strategi kepala sekolah dalam meningkatkan mutu sekolah dapat diatasi dengan baik dengan prinsip Crosby yaitu (Zero Defects) tanpa cacat. Usaha dengan didasari oleh komitmen yang kuat dari seluruh komponen sekolah dapat mencegah dan mengatasi segala kendala dengan cepat, efektif dan efisien sehingga orang tua peserta didik sebagai pelanggan eksternal tidak merasakan kerugian.

\section{SIMPULAN}

Untuk meningkatkan mutu sekolah, setiap pendidik dan tenaga kependidikan diberikan kepercayaan, semangat dan motivasi oleh kepala sekolah. Untuk menjamin mutu pada PAUD Pelangi, kepala sekolah selalu melakukan pengawasan dengan pendekatan kekeluargaan. Pimpinan berperan memberikan pengarahan dan pembinaan secara personal dan sebaliknya memberikan penghargaan bagi tenaga pendidik yang berprestasi.

Hambatan dalam upaya meningkatkan mutu pada PAUD Pelangi dibagi menjadi tiga yaitu, Pertama: berasal dari guru, belum adanya guru khusus yang dapat melatih keterampilan peserta didik pada bidang keterampilan. Kedua: minimnya fasilitas, sarana dan prasarana yang menunjang proses belajar mengajar dikelas. Kurangnya APE baik yang ada di dalam ruangan maupun di luar ruangan. Ketiga: lemahnya perhatian orang tua peserta 
didik terhadap perkembangan anak-anaknya, karena ketiadaan komite sekolah sebagai wadah komunikasi orang tua dan pengelola.

Upaya yang dapat dilakukan oleh kepala sekolah dalam meningkatkan mutu pada PAUD pelangi yang berkaitan dengan guru yang dapat memberikan pelatihan keterampilan pada peserta didik dengan mendatangkan guru khusus pada bidangnya. Untuk mengatasi hambatan pada fasilitas, sarana dan prasarana kepala sekolah melakukan penataan tempat maupun fungsi dari fasilitas dan sarana yang ada sehingga penggunaannya dapat terkontrol dengan baik, selain itu kepala sekolah melakukan kerja sama dengan beberapa pihak terutama kepada Pemerintah pusat dan Pemerintah daerah. Solusi yang diberikan kepala sekolah untuk meningkatkan perhatian dan kerja sama orang tua peserta didik dengan pihak sekolah adalah melalui pertemuan rapat sebanyak 3 kali dalam setahun dan adanya hari konsultasi perkembangan peserta didik yang dilaksanakan dari hari Kamis-Sabtu setelah kegiatan belajar mengajar.

\section{DAFTAR PUSTAKA}

Sagala, Syaiful. 2010. Manajemen Strategik Dalam Peningkatan Mutu Pendidikan. Bandung: Alfabeta

Sallis, Edward. 2015. Total Quality Manajement In Education.Yogyakarta: IRCiSoD Tim Penyusun, 2011. Manajemen Pendidikaan.Bandung:Alfabeta

Zaenab, Siti. 2015. Metodologi Penelitian Pendidikan Kualitatif:perspektif kekinian. Malang: Selaras

Latifah, Eva. "Implementasi Kurikulum Ting- kat Satuan Pendidikan di SMA Negeri Kabupaten Brebes". http//lonta rui.ac.id.

Kementerian Pendidikan dan Kebudayaan RI. Peran Guru dalam Implementasi

Kurikulum 2013. www.info.disikporabna.com. Diakses 23 Juni 2013.

Kementerian Pendidikan dan Kebudayaan RI. Pengembangan Kurikulum 2013. www.upi.edu.

Winataputra, Udin S. 2010. Kebijakan Nasional Pembangunan Karakter Bangsa melalui Pendidikan Karakter (Konsep, Kebijakan, dan Kerangka Programatik. Jakarta: Kementerian Koordinator Kesejahteraan RI. 
Tambunan Sony (2015). Pemimpin dan Kepemimpinan. Cet I; Yogyakarta: Graha Ilmu. Wahjosumidjo. 2007. Kepemimpinan Kepala Sekolah, Tinjauan Teoritik dan Permsasalahannya, Jakarta: PT. Raja Grafindo Persada.

Mulyasa (2012). Manajemen dan Kepemimpinana Kepala Sekolah, Jakarta: Bumi Aksara. Northouse, G. Peter. (2013). Kepemimpinan: Teori dan Praktek. Cet. VI; Jakarta: Penerbit Indeks. 